\title{
Effect of zafirlukast on capsular contracture around silicone implants in rats ${ }^{1}$
}

\author{
Efeito do zafirlukast na contratura capsular ao redor de implantes de silicone em ratos
}

\author{
Érika Malheiros Bastos", Miguel Sabino Neto", Élvio Bueno Garcia", Daniela Francescato Veiga"I, Yuri Anna Han" \\ Denadai $^{I v}$, Rafael de Almeida Santos ${ }^{\mathrm{v}}$, Lydia Masako Ferreira ${ }^{\mathrm{VI}}$
}

${ }^{\mathrm{I}} \mathrm{PhD}$, Associate Professor, Department of Surgery, School of Medical Sciences, University of Marilia (UNIMAR), Marilia-SP, Brazil. Main author. Conception, design, intellectual and scientific content of the study; acquisition, analysis and interpretation of data; manuscript writing, critical revision. IIPhD, Associate Professor, Plastic Surgery Division, UNIFESP, Sao Paulo-SP, Brazil. Supervised all phases of the study, manuscript writing and critical revision.

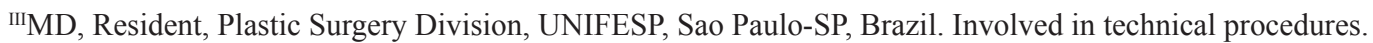

${ }^{\mathrm{IV}}$ Graduate student, School of Medical Sciences, UNIMAR, Marilia-SP, Brazil. Interpretation of data and manuscript writing, collection of study informations.

${ }^{\mathrm{v}} \mathrm{MD}$, Plastic Surgery Division, Brazilian Institute for Cancer Control (IBCC), Sao Paulo-SP, Brazil. Acquisition and interpretation of data, involved in technical procedures.

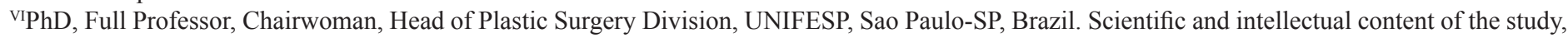
interpretation of data and critical revision.

\begin{abstract}
PURPOSE: To evaluate the effect of zafirlukast on capsular contracture around silicone implants by measuring the pressure within the implant, using a rat experimental model.

METHODS: Forty adult female Wistar rats were used. Each one received two silicone implants, one with smooth-surface and the other with textured-surface. They were randomly divided into four groups $(n=10)$. The rats of control group I were sacrificed after the implants. The remaining animals were subjected to a daily regimen of intra-peritoneal injection for a period of 90 days and they were distributed as follows: control group II received $0.9 \%$ physiological saline solution; experimental group I received zafirlukast $1.25 \mathrm{mg} / \mathrm{kg}$; and experimental group II received zafirlukast $5 \mathrm{mg} / \mathrm{kg}$. The measurement of intra-implant pressure of control group I was determined on the surgery day and in other groups on the ninetieth day, after being sacrificed. RESULTS: In the evaluation of textured implants there was an increase of internal pressure in the control group II, and there was no increase in the experimental groups. Compared to the controls there were not significant differences in smooth implants.
\end{abstract}

CONCLUSION: Zafirlukast reduced the risk of developing capsular contracture around silicone implants with textured surface.

Key words: Breast Implants. Implant Capsular Contracture. Leukotriene Antagonists. Rats.

\section{RESUMO}

OBJETIVO: Avaliar o efeito do zafirlukast na contratura capsular ao redor de implantes de silicone, através da aferição da pressão intra-implante, utilizando-se um modelo experimental de ratos.

MÉTODOS: Quarenta ratos fêmeas Wistar foram utilizados. Cada um recebeu dois implantes de silicone, sendo um com superfície lisa e outro texturizada. Foram divididos aleatoriamente em quatro grupos $(\mathrm{n}=10)$. Os ratos do grupo controle I foram sacrificados após o implante. O restante dos animais foi submetido a um regime diário de injeção intraperitoneal por um período de 90 dias e foram distribuídos: grupo controle II recebeu solução salina fisiológica $0,9 \%$, grupo experimental I recebeu zafirlukast 1,25 $\mathrm{mg} / \mathrm{kg}$, e grupo experimental II recebeu zafirlukast $5 \mathrm{mg} / \mathrm{kg}$. O grupo controle II recebeu solução salina; grupo experimental I, 1,25 mg/kg/dia de zafirlukast; grupo experimental II, $5 \mathrm{mg} / \mathrm{kg} /$ dia de zafirlukast. A aferição da pressão intra-implante do grupo controle I foi averiguada no dia do ato operatório, e nos outros grupos no nonagésimo dia, após serem sacrificados.

RESULTADOS: Na avaliação dos implantes texturizados houve aumento da pressão interna no grupo controle II e, não se observou aumento nos grupos experimentais. Na comparação com os controles não foram observadas diferenças significativas nos implantes lisos. CONCLUSÃO: O Zafirlukast reduziu o risco de desenvolver contratura capsular em torno de implantes de silicone com superfície texturizada.

Descritores: Implantes de Mama. Contratura Capsular em Implantes. Antagonistas de Leucotrienos. Ratos. 


\section{Introduction}

The search for breast implant surgery is increasing each year. According to the American Society for Aesthetic Plastic Surgery (ASAPS) ${ }^{1}$, in 2009, over 289.000 procedures were conducted exclusively for breast augmentation. In Brazil, according to the Brazilian Society of Plastic Surgery (SBCP) ${ }^{2}$, this number is over 150.000 .

In this type of surgery, the capsular contracture is the main complication ${ }^{3,4}$ observed in up to $50 \% 0^{4,5}$ of patients in two years following the surgery ${ }^{3-7}$. The fibrous tissue formed around the prosthesis promotes its compression and can cause esthetic involvement (distortion, asymmetry and hardening of the breast) and painful symptoms ${ }^{4-9}$, making it sometimes frustrating for both patients and surgeons ${ }^{5,6}$.

The standard treatment is capsulectomy with implant replacement, which would require additional surgery, with all its risks and inherent burdens $s^{3,6-10}$. The search for prevention and less morbid/invasive treatment for this phenomenon has been the subject of several studies; however, so far, no study has clearly demonstrated their effectiveness ${ }^{3-11}$.

Although the actual cause of capsular contracture is still unknown, most authors rely on the hypothesis of a multifactorial process $^{3-5,7-9}$ that has inflammation as a common denominator ${ }^{3,7,8}$. Currently, pharmacological inhibition of this inflammation around implants is the main focus of investigation ${ }^{7,8}$, in the search for prevention and successful treatment of this problem ${ }^{3,7,8}$.

It deserves mention a pioneering study conducted by Schlesinger et al. ${ }^{12}$, which showed a significant improvement in the degree of capsular contracture with the use of zafirlukast (Accolate $^{\circledR}$, AstraZeneca), a leukotriene antagonist, for a period of 1 to 3 months, to the extent that, in cases of some women for whom surgical procedures had already been indicated, this proved unnecessary. As a consequence, some authors have attempted to clarify the issue of the mechanisms involved with this drug in the prevention and treatment of capsular contracture $5,8,10-18$. Accordingly, new investigations are important to confirm the beneficial effect of this drug.

The purpose of this experimental study is to evaluate the effect of zafirlukast on capsular contracture around silicone implants by measuring the pressure within the implant, using a rat experimental model.

\section{Methods}

The experimental protocol was approved by the Research Ethics Committee of the Federal University of Sao Paulo (UNIFESP). The rats were kept according to the guidelines of the Guide for the Care and Use of Laboratory Animals (Institute for Laboratory Animal Research, 1996) and according to the ethical principles of the Brazilian College on Animal Experimentation (COBEA).

Forty adult female Wistar EPM-1 rats weighing 200 to $250 \mathrm{~g}$ were used. The animals were kept in light-dark cycles $(12 / 12 \mathrm{~h})$ with free access to food and water. All surgical procedures were performed under general anesthesia by intraperitoneal administration of $25 \mathrm{mg} / \mathrm{kg}$ of tiletamine hydrochloride/ zolazepam hydrochloride (Zoletil ${ }^{\circledR}$, VIRBAC, Sao Paulo, Brazil).

\section{Experimental groups and surgical procedure}

On surgeries, a total of 80 mini silicone implants filled with silicone gel, round-based, $2.2 \mathrm{~cm}$ in diameter, volume of two $\mathrm{ml}$ and with the same internal pressure were used. Forty mini-implants had textured-surfaces and 40 smooth-surfaces. All were produced and donated by the company SILIMED ${ }^{\circledR}$ (Rio de Janeiro, Brazil).

Surgical procedures were carried out according to the experimental model of capsular contracture in silicone implants previously reported by our group ${ }^{19}$. Rats underwent a two-cm incision perpendicular and symmetrical to the midline, between the middle and distal thirds of the animals back (between the posterior-superior iliac spines), involving skin and panniculus carnosus.

Following, two tunnels were built beneath the panniculus carnosus, until and between the shoulder blades, on each side of the animal, taking care not to communicate them. The implants were inserted through the incision and placed on the scapulas; the smooth surface implants were positioned on the right and the textured ones on the left (Figure 1). 


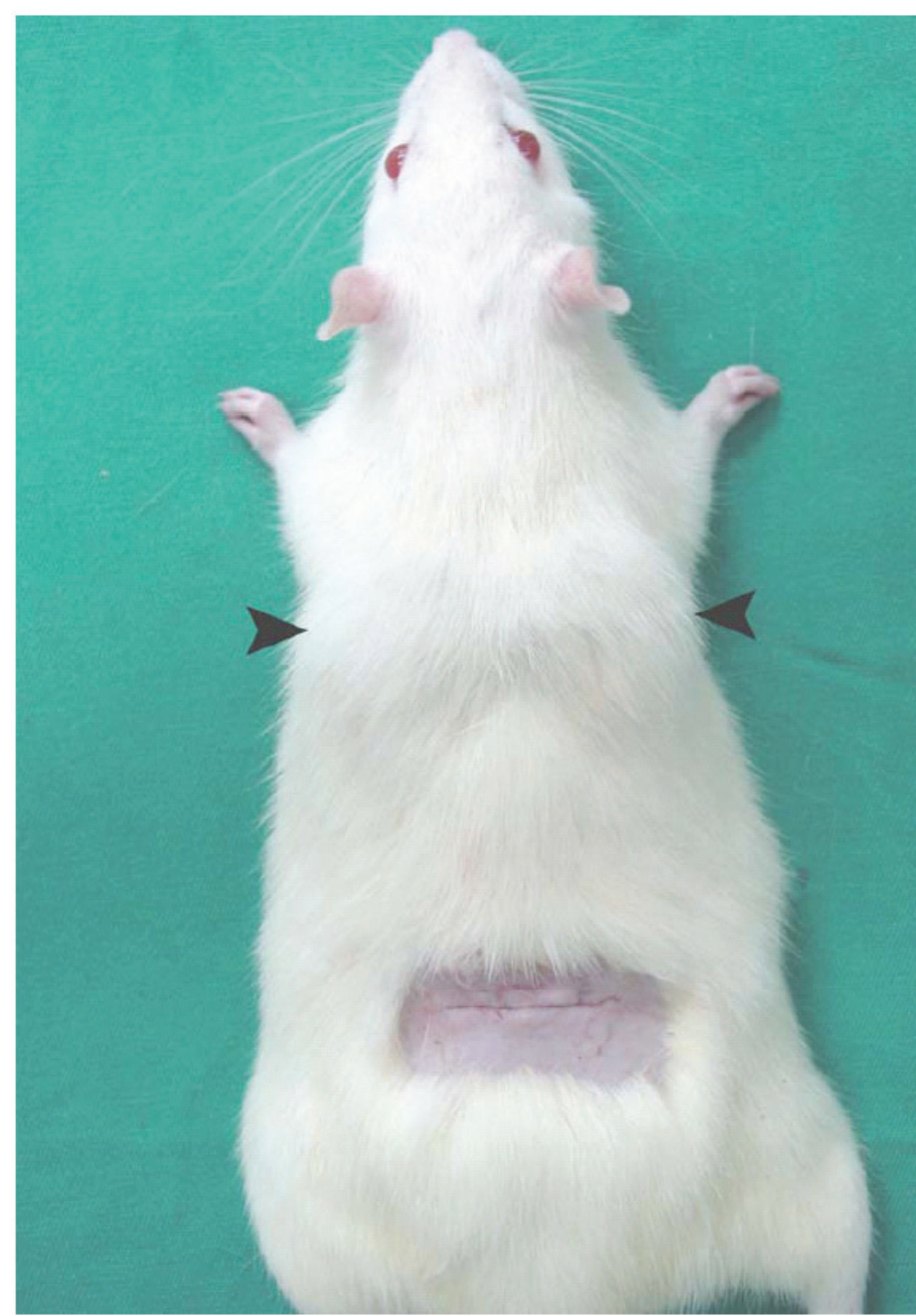

FIGURE 1 - Rat after placement of implants on the scapulas (arrows).

Following this phase, four groups of 10 rats were formed at random. The control group I (CI) received only the implantation of prostheses. The remaining animals were subjected to a daily regimen of intra-peritoneal injections for a period of 90 days and they were distributed as follows: control group II (CII) received $0.9 \%$ physiological saline solution; experimental group I (EI) received zafirlukast $1.25 \mathrm{mg} / \mathrm{kg}$; and experimental group II (EII) received zafirlukast $5 \mathrm{mg} / \mathrm{kg}$. The animals of CI group were sacrificed on the day of surgery and the remaining ones after 90 days, by a lethal anesthetic dose.

\section{Measuring the internal pressure of mini-implants}

To measure the internal pressure of each implant was performed the pressure measurement generated by the influx of distilled water into the implant; after the opening of the paths that connected the implant to the gauge it was made the reading of this reflux pressure, which inferred the compliance of the capsule
(Figure 2). For this, it was used a pressure transducer, which transformed the mechanical information of pressure into electrical signals and a signal amplifier $\left(\right.$ TIVA $^{\circledR}$, VECTUS, Sao Paulo, Brazil), which read the electrical signals and transformed them into Pascal measurements (0 to 1500 Pascal).

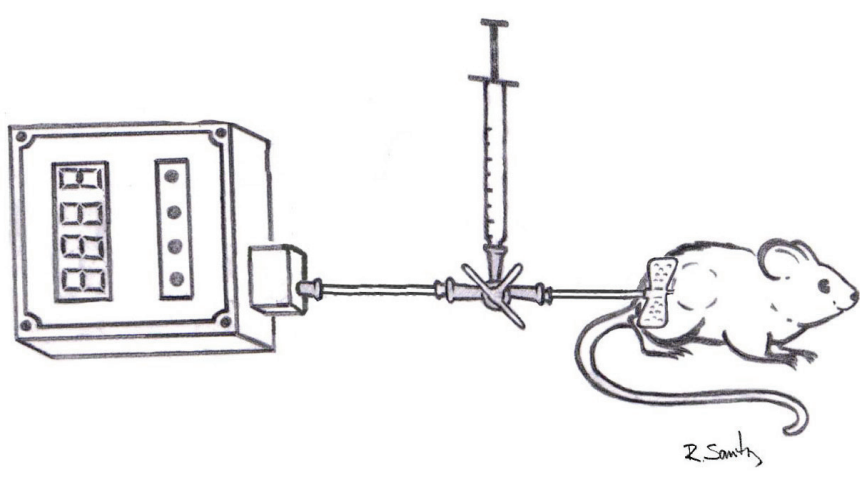

FIGURE 2 - Illustration showing the layout of pressure measurement inside the mini-implants after distilled water infusion. Water is injected into the implant and then ways of the pressure gauge and implant are maintained patent for water reflux, which occurs according to the complacency of the capsule. The mechanical energy is transformed into an electrical signal that is read by the device.

The pressure transducer was connected to the gaugereader. A silicone hose was connected to another output. This hose was connected to a three-way system. In one of the ways it was connected a syringe of $1 \mathrm{ml}$; and in the other one, a $\mathrm{n}^{\circ} 19$ scalp. The whole system was filled with distilled water; the transducer and the silicone hose were filled previously and connected to the system, taking care not to let any air bubbles. This system remained untouched (without disconnecting) until the end of the measurements.

The scalp, which was changed at every measurement, was connected to the system and filled with distilled water through the syringe connected to the other way. After the system was fully filled, the ways from the scalp to the gauge were opened, and the initial value of zero was verified (based on atmospheric pressure). The syringe was then filled with $0.5 \mathrm{ml}$ of distilled water and reconnected to the system.

After removal of hair over the implant area, they were positioned at the same level of the system and the "scalp" was introduced into the animal (always the same length of the needle was inserted into the animal). Great care was taken that all connections were at the same level of "zero" calibrated, including the needle inserted into the rat, which had 90 degrees with the syringe in all axes.

Since the gel is very viscous, it did not flow into the 
system; therefore, a controlled amount of this fluid $(0.3 \mathrm{ml})$ was injected into the implant through the syringe. After this procedure, the ways of the reader and of the scalp were open, so that according to the internal pressure of the mini-implants there was a variable reflux of water into the transducer, which transformed this mechanical signal into electrical signals read by the reader as a Pascal pressure measurement.

\section{Statistical analysis}

In the descriptive analysis, data were summarized as means, medians, standard deviations, standard errors, $1^{\text {st }}$ and $3^{\text {rd }}$ quartiles, minimum and maximum values. For comparisons between groups and between types of implants generalized linear models were used with repeated measures considering two factors: group (CI, CII, EI and EII) and type of implant (smooth and textured). The used statistical programs were: Statistical Package for Social Sciences (SPSS) version 11.0 and SAS version 8.01 for Windows. Values were considered significant for a confidence interval of $95 \%(p<0.05)$.

\section{Results}

The final sample analyzed consisted of 33 rats, carrying 33 smooth implants and 31 textured ones. One animal in CI group showed extrusion of two implants and two animals presented implants attached to each other; therefore, they were excluded (remaining 7 rats, 7 smooth, and 7 textured). In group EI one rat was sacrificed due to eye loss caused by local infection; a rat with implants adhered to one another and a loss by measurement error (remaining 7 rats, 7 smooth, and 7 textured). In EII group one rat died of peritonitis because of a probable accident puncture; and two rats with loss of textured implants after necrosis of the overlying skin (remaining 9 rats, 9 smooth, and 7 textured).

\section{Internal pressure of mini-implants}

The value distribution of internal pressures of miniimplants, after the infusion of $0.3 \mathrm{ml}$ of distilled water, in the four groups, is shown in form of box-plot in Figure 3.

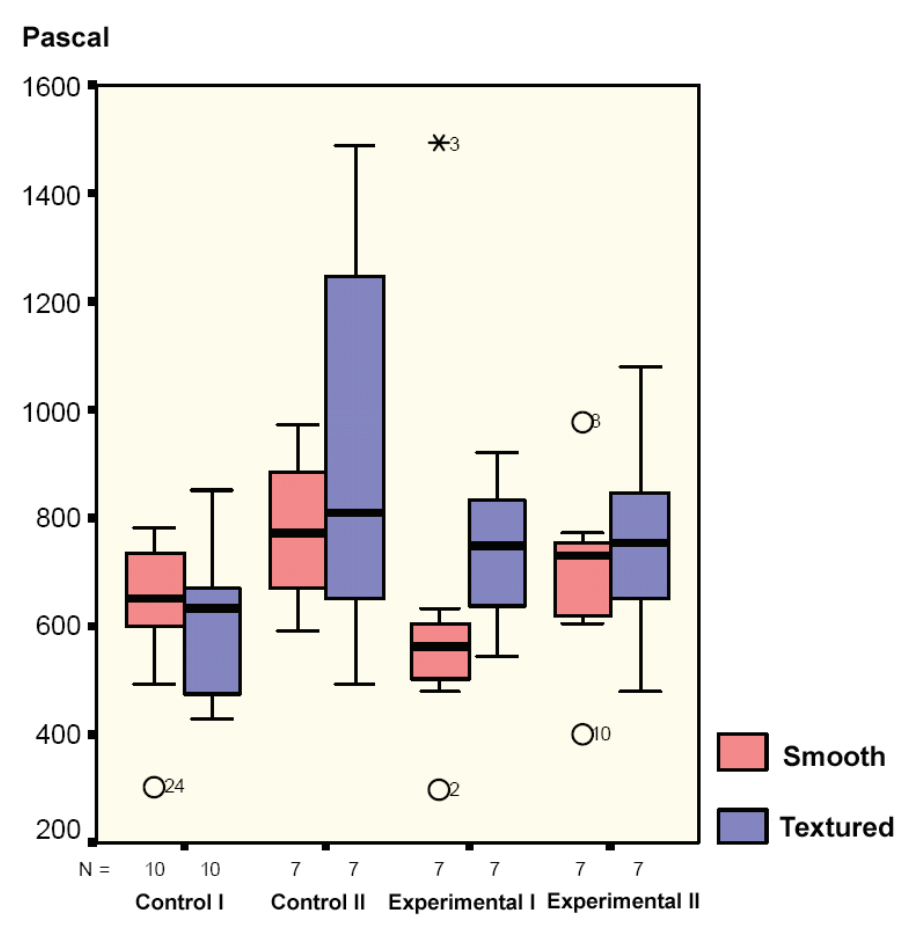

FIGURE 3 - Boxplot showing the dispersion of the values of intraimplant pressure after infusion of $0.3 \mathrm{ml}$ of distilled water in the four

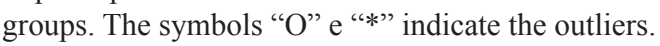

Analyzing the variations of internal pressure of the textured implants, it was found a significant difference $(\mathrm{p}=0.0047)$ between $\mathrm{CI}$ and CII, with the later showing the highest postinfusion pressure, which can be characterized as capsular contracture. In the comparison of CI group with experimental groups (EI and EII) no difference was found, which indicates that these groups (EI and EII) showed no capsular contracture. In groups with smooth implants capsular contracture was not found either in the group that received only saline solution or in groups that received zafirlukast (Table 1).

The comparative analysis between implant types (textured and smooth) for all groups showed no differences (Table 2).

TABLE 1 - Comparative analysis group by group among pressures encountered, according to the type of implant surface.

\begin{tabular}{ccc}
\hline \multirow{2}{*}{ Comparison } & \multicolumn{2}{c}{ p-value } \\
\cline { 2 - 3 } & Smooth & Textured \\
\hline CI X CII & 0.1925 & $0.0047^{*}$ \\
CI X EI & 0.8383 & 0.2337 \\
CI X EII & 0.4781 & 0.1657 \\
CII X EI & 0.3068 & 0.0995 \\
CII X EII & 0.5211 & 0.1413 \\
EI X EII & 0.6533 & 0.8509 \\
\hline
\end{tabular}

$\mathrm{CI}=$ control group $\mathrm{I}$; $\mathrm{CII}=$ control group II; EI = experimental group I; EII $=$ experimental group II. *Statistically significant. 
TABLE 2 - Comparative analysis of the pressures found according to the type of implant surface in the four groups.

\begin{tabular}{cc}
\hline Comparison & p-value \\
\hline Smooth $x$ Textured (CI) & 0.7809 \\
Smooth $x$ Textured (CII) & 0.1698 \\
Smooth $x$ Textured (EI) & 0.4760 \\
Smooth $x$ Textured (EII) & 0.6152 \\
\hline
\end{tabular}

$\mathrm{CI}=$ control group $\mathrm{I}$; $\mathrm{CII}=$ control group II; EI = experimental group I; EII = experimental group II.

\section{Discussion}

Since the first reports on capsular contracture in the literature, many studies have been conducted in an attempt to prevent its development, using different drugs (such as antibiotics, anti-neoplastic agents and steroids) administered locally or systemically, but with disappointing results $\mathrm{s}^{3-6,8,10,11}$.

It deserves attention the possibility of an oral drug for the treatment of a complication that has serious physical, psychological and financial consequences and for which the only effective treatment is surgery ${ }^{14}$. Zafirlukast is commonly used in the treatment of asthma. It is a competitive antagonist of leukotriene receptor D4 and E4 and the occupation of these receptors by cysteinyl leukotrienes has been implicated in the pathophysiology of asthma, acting in stages such as contraction of bronchial smooth muscles, determining, among other actions, the reduction of airway edema, alteration of cellular activity related to inflammation, preventing the increase of vascular permeability and inhibition of eosinophil influx ${ }^{20}$.

Recent research has shown that its use in animals ${ }^{10,13,14}$ and clinical trials ${ }^{8,12,15-17}$ determines a reduction in capsular formation around the silicone implants ${ }^{10,13,14}$. The use of zafirlukast also reduces pain, distortion of breast ${ }^{8,15,16}$ and can reverse up to two degrees (according to Baker's classification) in the contracture of capsules already established ${ }^{8}$. Biomolecular studies $^{5,11}$ demonstrated that leukotriene receptors (CysLT) are involved in the formation of fibrous capsules around the breast implants. All these data add to speculation about the importance of leukotriene antagonists in the prevention and treatment of capsular contracture.

In this study, the option for silicone prostheses and not saline ones was due to the greater incidence of capsular contracture found in the use of the former'; the observation time (three months) was based on other studies with rats, which showed that most of the capsular contractures occurred during this period ${ }^{21}$. As for the method of measuring the complacency of the capsule, it was chosen the method of infusion liquid which had been described by other authors ${ }^{21-23}$. The use of pressure measurement system was necessary because it seems to be the most objective method to assess capsular contracture. Baker's classification and applanation tonometry did not seem very appropriate to investigate contractures in rats.

The use of implants with textured and smooth surfaces was due to the fact that they behave differently regarding the occurrence of capsular contracture ${ }^{6,7}$; however, this matter is not yet consensus in the scientific literature ${ }^{7}$. Therefore, it was opted for the allocation of two types of prostheses in the same rat, so that different responses to the use of zafirlukast could be verified.

The effect of zafirlukast in reducing capsular contracture on textured implants observed in this experiment is consistent with findings from previous studies ${ }^{10,13,14}$, which showed that the application of leukotriene antagonist reduced the number of vessels, capsular thickness, collagen density, number of mast cells, eosinophils and myofibroblasts around the prosthesis compared with control. However, the issue of smooth prostheses lacks further responses.

Besides the zafirlukast reducing the formation of capsule around implants (demonstrated in previous studies ${ }^{10,13,14}$, the decrease of the contraction had not been demonstrated and by measuring the internal pressures of mini-implants, the present study comes to fill this gap.

\section{Conclusion}

Zafirlukast reduced the risk of developing capsular contracture around silicone implants with textured surface in this rat model.

\section{References}

1. American Society for Aesthetic Plastic Surgery. [ASAPS web site]. Available from http://www.surgery.org. Accessed November 26, 2010.

2. Brazilian Society of Plastic Surgery. [Sociedade Brasileira de Cirurgia Plástica (SBCP) web site]. Available at: http://www. cirurgiaplastica.org.br. Accessed November 26, 2010.

3. Adams WP Jr. Capsular contracture: what is it? What causes it? How can it be prevented and managed? Clin Plast Surg. 2009;36(1):11926.

4. Adams WP Jr, Haydon MS, Raniere J Jr, Trott S, Marques M, Feliciano M, Robinson JB Jr, Tang L, Brown SA. A rabbit model for capsular contracture: development and clinical implications. Plast Reconstr Surg. 2006;117(4):1214-9.

5. D'Andrea F, Nicoletti GF, Grella E, Grella R, Siniscalco D, Fuccio 
C, Rossi F, Maione S, De Novellis V. Modification of cysteinyl leukotriene receptor expression in capsular contracture: preliminary results. Ann Plast Surg. 2007;58(2):212-4.

6. Barnsley GP, Sigurdson LJ, Barnsley SE. Textured surface breast implants in the prevention of capsular contracture among breast augmentation patients: a meta-analysis of randomized controlled trials. Plast Reconstr Surg. 2006;117(7):2182-90.

7. Araco A, Caruso R, Araco F, Overton J, Gravante G. Capsular contractures: a systematic review. Plast Reconstr Surg. 2009;124(6):1808-19.

8. Scuderi N, Mazzocchi M, Fioramonti P, Bistoni G. The effects of zafirlukast on capsular contracture: preliminary report. Aesthetic Plast Surg. 2006;30(5):513-20.

9. Embrey M, Adams EE, Cunningham B, Peters W, Young VL, Carlo GL. A review of the literature on the etiology of capsular contracture and a pilot study to determine the outcome of capsular contracture interventions. Aesthetic Plast Surg. 1999;23(3):197-206.

10. Spano A, Palmieri B, Taidelli TP, Nava MB. Reduction of capsular thickness around silicone breast implants by zafirlukast in rats. Eur Surg Res. 2008;41(1):8-14.

11. Grella E, Grella R, Siniscalco D, Fuccio C, Rossi F, De Novellis V, Maione S, D'Andrea F. Modification of cysteinyl leukotriene receptors expression in capsular contracture: follow-up study and definitive results. Ann Plast Surg. 2009;63(2):206-8.

12. Schlesinger SL, Ellenbogen R, Desvigne MN, Svehlak S, Heck R. Zafirlukast (Accolate): a new treatment for capsular contracture. Aesthetic Surg J. 2002;22(4):329-6.

13. Moreira M, Fagundes DJ, de Jesus Simões M, de Oliveira MC, Dos Santos Previdelli IT, Moreira AC. Zafirlukast pocket delivery impairs the capsule healing around textured implants in rats. Aesthetic Plast Surg. 2009;33(1):90-7.

14. Bastos EM, Neto MS, Alves MT, Garcia EB, Santos RA, Heink T, Pereira JB, Ferreira LM. Histologic analysis of zafirlukast's effect on capsule formation around silicone implants. Aesthetic Plast Surg. 2007;31(5):559-65.

15. Scuderi N, Mazzocchi M, Fioramonti P, Palumbo F, Rizzo MI, Monarca C, Onesti MG. Treatment of the capsular contracture around mammary implants: our experience. G Chir. 2008;29(89):369-72.

16. Scuderi N, Mazzocchi M, Rubino C. Effects of zafirlukast on capsular contracture: controlled study measuring the mammary compliance. Int J Immunopathol Pharmacol. 2007;20(3):577-84.

17. Reid RR, Greve SD, Casas LA. The effect of zafirlukast (Accolate) on early capsular contracture in the primary augmentation patient: a pilot study. Aesthetic Surg J. 2005;25(1):26-30.

18. Schlesinger SL, Desvigne MN, Ellenbogen R, Svehlak S, Heck R. Results of using zafirlukast (Accolate) and montelukast (Singulair) for treatment of capsular contracture. Aesthetic Surg J. 2003;23(2):101-2.

19. Bastos EM, Neto MS, Ferreira LM, Garcia EB, Liebano RE, Han YA. Experimental model of capsular contracture in silicone implants. Acta Cir Bras. 2003;18(special issue):22-8.
20. Findlay SR, Barden JM, Easley CB, Glass M. Effect of the oral leukotriene antagonist, ICI 204,219, on antigen-induced bronchoconstriction in subjects with asthma. J Allergy Clin Immunol. 1992;89(5):1040-5.

21. Clugston PA, Perry LC, Hammond DC, Maxwell GP. A rat model for capsular contracture: the effects of surface texturing. Ann Plast Surg. 1994;33(6):595-9.

22. Peters CR, Shaw TE, Raju DR. The influence of vitamin E on capsule formation and contracture around silicone implants. Ann Plast Surg. 1980;5(5):347-52.

23. Bucky LP, Ehrlich HP, Sohoni S, May JW Jr. The capsule quality of saline-filled smooth silicone, textured silicone, and polyurethane implants in rabbits: a long-term study. Plast Reconstr Surg. 1994;93(6):1123-31; discussion 1132-3.

\section{Acknowledgments}

The authors express their gratitude to SILIMED ${ }^{\circledR}$ and the AstraZeneca for donating the mini-implants and Zafirlukast, respectively; Escola Politécnica da USP - Poli Jr. and the mechanical engineer Wili Coloza Hofmann by technical advice; to Prof. Dr. Jobenil Magalhães by statistical analysis.

\section{Correspondence:}

\section{Érika Malheiros Bastos}

Depto. Cirurgia, Faculdade de Ciências Médicas

Universidade de Marília

Rua Carlos Botelho, 376

17515-240 Marília - SP Brasil

Tel./Fax: (55 14)3432-2889

erika.mb@uol.com.br

Received: August 10, 2011

Review: October 14, 2011

Accepted: November 16, 2011

Conflict of interest: none

Financial source: none

${ }^{1}$ Research performed at Postgraduate Program in Plastic Surgery, Federal University of Sao Paulo (UNIFESP), Brazil. 